Journal of Environmental Sciences (JES)

Institute of Environmental Studies and Research, Ain Shams University

Abdel kader, Eman et al.

\title{
THE ENVIRONMENTAL IMPACT ASSESSMENT OF HARVESTING WATER FROM FLASH FLOODS (CASE STUDY ON SAINT CATHERINE AREA - SOUTHERN SINAI)
}

Eman M. Abdel $\operatorname{kader}^{(1)}$; Ezzat M. Soliman ${ }^{(2)}$ and Gamal A. Kamel ${ }^{(1)}$ 1) Water Resources Research Institute, National Water Research Center.

2) Institute of Environmental studies and Research, Ain Shams University.

\begin{abstract}
A Flash Flood is a flood that follows the causative event (excessive rain, dam or level failure...etc) within a few hours. It can be mitigated by managing and controlling the water movement by redirecting flood run-off through the use of flood walls and flood gates. The current study aims at investigating the Environmental Impact Assessment of, the flash flood and the construction of walls to reduce the movement of water and harvesting it in constructed mountainous lake. The harvested water used in cultivation Tomato and cucumber in green houses. The EIA reveal the positive impact of constructing lake and using the harvested water in cultivation on the social, economy and biodiversity items.
\end{abstract}

Key words: flood mitigation, constructed mountainous, cultivation in green house, Environmental Impact Assessment (EIA).

\section{INTRODUCTION}

Floods are caused by a high flow of water, from precipitation (rain, melting snows etc...) if there is more water than the land can naturally deal with through the water table, ground water flow and channels (rivers/lakes etc...) and the land is already saturated flooding will occur rivers will break 
Journal of Environmental Sciences (JES)

Institute of Environmental Studies and Research, Ain Shams University

Abdel kader, Eman et al.

their banks and spread onto their flood plains, the water table will rise and ground water flow will increase where there are no channels. Some effects are the devastation in poorer countries caused by flash floods and the shifting of sediments (mud slides). (Alzayed... et al., 2013).

One of the most common incidences of flash flooding occurs when there is a heavy period of rainfall following a period of drought. This is because the ground is very dry and cannot absorb so much water at once. Then when the torrent of water comes, it cannot be absorbed into the ground and spills over and when rain keeps persisting in such a way, it can wash away land and cause great damage to buildings (in a flash flood).

A trend towards an increasingly drier and more variable climate has significantly increased global incidences of intense (extreme) precipitation events in the 20th century at the expense of more moderate events (IPCC, 2001). The impact of this change in climate is particularly felt in semi-arid (annual rainfall is $250-500 \mathrm{~mm} / \mathrm{year}$ ) and arid (annual rainfall is less than 250 $\mathrm{mm} / \mathrm{year}$ ) regions of the world. This change has lead to a continuous increase in damages due to extreme flood events, despite widespread.

The objectives of this study are summarized as follow.

- Identify the methodology of harvesting the flash flood water.

- Application of Environmental Impact Assessment EIA Matrix to identify the importance harvesting that water. 
Journal of Environmental Sciences (JES)

Institute of Environmental Studies and Research, Ain Shams University

Abdel kader, Eman et al.

\section{MATERIALS AND METHODS}

Selection of water harvesting sites and techniques was based on integrated water resources management (IWRM) guidelines to obtain a sustainable development for any implemented project (GWP, 2000). Accordingly, rainfall data, topography data and Geological data are collected and combined to estimate the volume of the flash flood.

\section{STUDY AREA}

Data Analysis: In order to study the Environmental Impact Assessment of harvesting the water of flash flood, it is important to study the hydrological characters of the peak flow and the expected quantities of water during different return periods such as 2, 5, 10 years. To achieve this objective a huge amount of data was collected and analyzed including rainfall data, topographic map, stalactite images demographic data, etc. details of these collected and analyzed data were presented in the following paragraphs.

Topography: The highest ground level is represented in the central part of the study area where it attains altitude ranges between 1900 to $2600 \mathrm{~m}$. amsl. The highest level degraded towards the borders of the study to reach the lowest ground level in the north west and west directions (altitude ranges between $460-1100 \mathrm{~m}$. amsl). The most high mountainous features in the area of study are Catherine mountain, Abo Romel mountain, El Monagaa mountain and Mosa mountain, while the most lowest area is represented by Wadi El Arbeen which is the main source for water flood. 
Journal of Environmental Sciences (JES)

Institute of Environmental Studies and Research, Ain Shams University

Abdel kader, Eman et al.

Rainfall: The analysis focused on the statistical analysis of rainfall series. Statistical analysis was carried out for the maximum daily rainfall data series of all stations to obtain the rainfall depths corresponding to different return periods 5, 10, 25, 50, 100 and 500 year. Several statistical analysis programs, such as HYFRAN, Hydro freq, freq, were used to analyze the data.

Geology: Generally the area of study is covered mainly by basement rocks and Quaternary deposits. (Coral, 1987) stated that the upstream of Wadi Feiran Basin where Saint Catherine area is mainly composed of Igneous rocks. The crystalline Precambrian rocks of the region represent part of the Arabian Shield which extends from central Sinai to the Gulf of Aden.

The different litho-stratigraphic units were identified and exposed in Saint Catherina. Those two units can be classified into two units from older to younger as follows:

- Pre-Cambrian Basement Rocks

- The Quaternary Deposits

Water Quantity: Flash flood water are calculated using the application of the Watershed Modelling Simulation WMS, which developed firstly by Brigham Young University (USA 2004) and currently developed by AQUAVEO.

With the absence of the runoff hydrographs measurements in the study area, synthetic unit hydrograph methods are used, instead, to calculate the characteristics of the surface runoff. The synthetic unit hydrograph of the Soil Conservation Service (SCS) is one of the recommended methods. It is based 
on a dimensionless unit hydrograph developed from an analysis of a large number of unit hydrographs.

Then, flash flood hydrograph is obtained as show in figure (1)

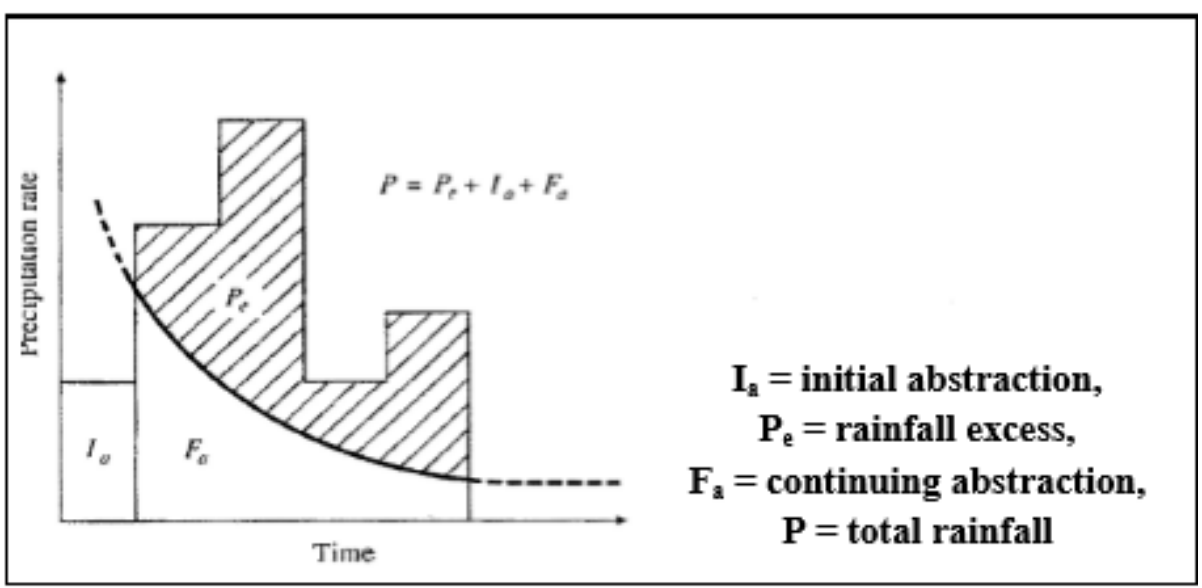

Figure(1): Schematic of the abstraction from rainfall storm (Chow et al, 1988)

Table (1) presents the characters of the different results of the peak flow, volume of water and time of peak. Figure (2) shows the output of the hydrograph that used with different return periods (2, 5 and 10 years).

Table (2) presents also the hydrological characteristics of the peak flow and the volume water and the time of peak for the return periods of 25,50 and 100 years in addition to the time of the peaks per hours. Figure (3) show the output hydrograph of the return periods of 25,50 and 100 years.

The table shows that the quantities of water increase with the increase of time. 
Journal of Environmental Sciences (JES)

Institute of Environmental Studies and Research, Ain Shams University

Abdel kader, Eman et al.

Table(1): Hydrological Characteristics of 2, 5, 10 return period

\begin{tabular}{|c|c|c|c|c|c|c|c|c|c||}
\hline \hline \multirow{2}{*}{$\begin{array}{c}\text { Name } \\
\text { of wadi }\end{array}$} & \multicolumn{8}{|c|}{ Characteristics of the Results } \\
\cline { 2 - 10 } & \multicolumn{2}{|c|}{ Peak Flow m3/Sec. } & \multicolumn{3}{|c|}{ Volume m3 } & \multicolumn{2}{c|}{ Time to Peak (hours) } \\
\hline \multirow{2}{*}{$\begin{array}{c}\text { El } \\
\text { Arbeen }\end{array}$} & 2 year & 5 year & $\begin{array}{c}10 \\
\text { year }\end{array}$ & 2 year & 5 year & 10 year & 2 year & 5 year & $\begin{array}{c}10 \\
\text { year }\end{array}$ \\
\cline { 2 - 11 } & 0.5 & 10.3 & 21.6 & 2606.4 & 61434 & 136602.9 & 2.75 & 2.5 & 2.5 \\
\hline
\end{tabular}

Flow vs. Time

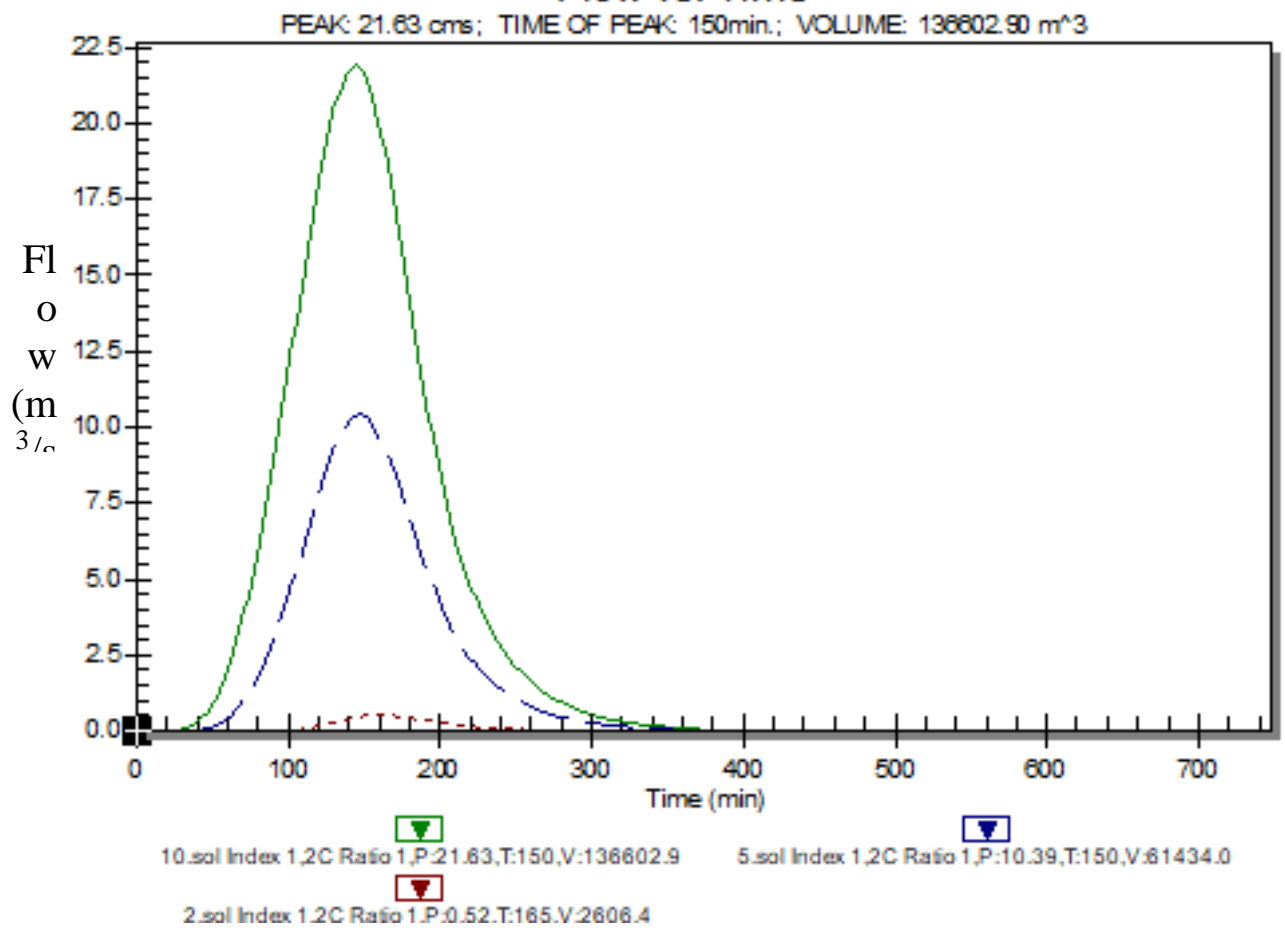

Figure(2): The output hydrograph at return periods (2, 5, $10 \mathrm{yr}$.) 
Journal of Environmental Sciences (JES)

Institute of Environmental Studies and Research, Ain Shams University

Abdel kader, Eman et al.

Table (2): Hydrological Characteristics of 25, 50, 100 return period

\begin{tabular}{|c|c|c|c|c|c|c|c|c|c|}
\hline \multirow[b]{2}{*}{$\begin{array}{l}\text { Name of } \\
\text { Wadi }\end{array}$} & \multicolumn{9}{|c|}{ Characteristics of the Results } \\
\hline & \multicolumn{3}{|c|}{ Peak Flow m3/Sec. } & \multicolumn{3}{|c|}{ Volume m3 } & \multicolumn{3}{|c|}{$\begin{array}{c}\begin{array}{c}\text { Time to Peak } \\
\text { (hours) }\end{array} \\
\end{array}$} \\
\hline \multirow{2}{*}{ El Arbeen } & $\begin{array}{c}25 \\
\text { year }\end{array}$ & $\begin{array}{c}50 \\
\text { year }\end{array}$ & $\begin{array}{l}100 \\
\text { year }\end{array}$ & $\begin{array}{c}25 \\
\text { year }\end{array}$ & $\begin{array}{c}50 \\
\text { year }\end{array}$ & $\begin{array}{l}100 \\
\text { year }\end{array}$ & $\begin{array}{c}25 \\
\text { year }\end{array}$ & $\begin{array}{c}50 \\
\text { year }\end{array}$ & $\begin{array}{l}100 \\
\text { year }\end{array}$ \\
\hline & 39.9 & 56.3 & 73.9 & 264409.2 & 380076.3 & 507030.3 & 2.25 & 2.25 & 2.25 \\
\hline
\end{tabular}

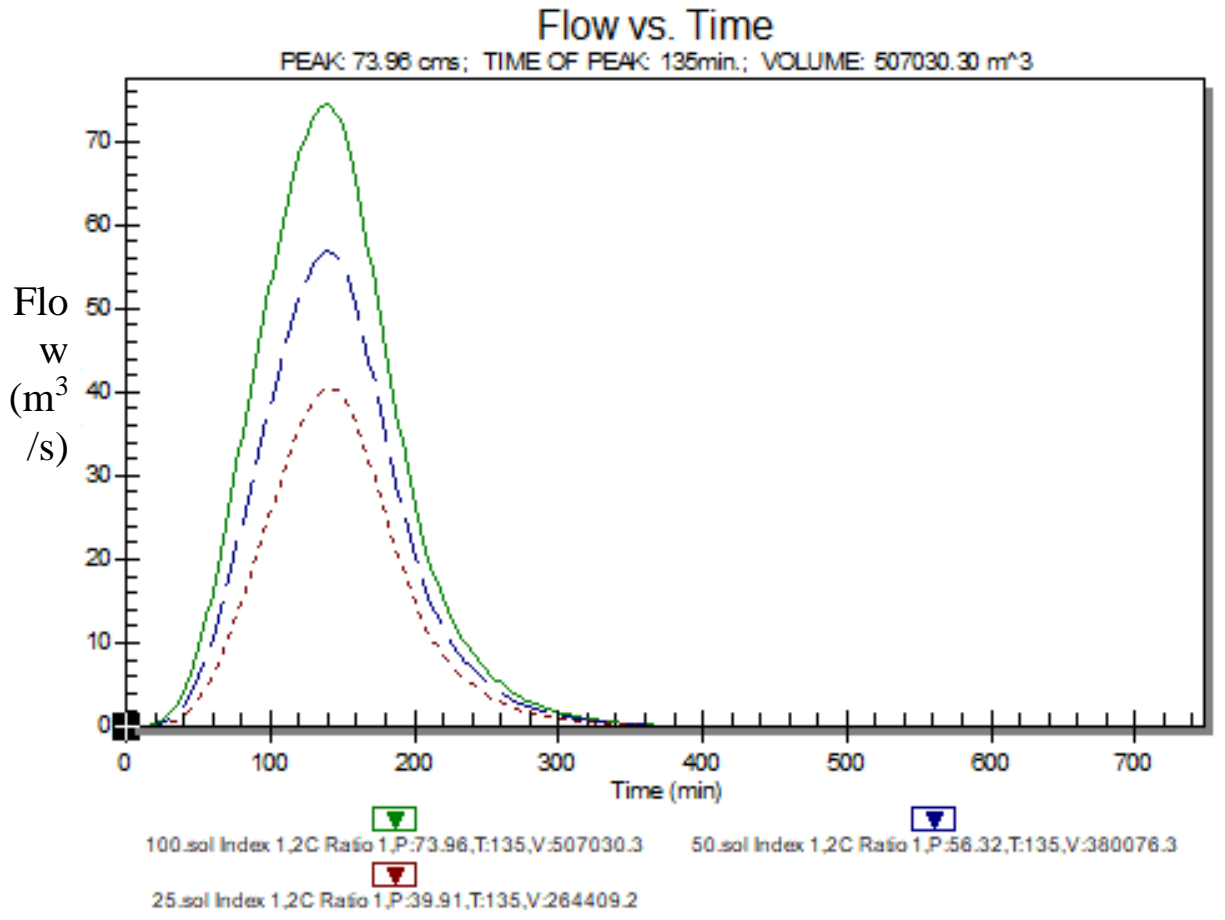

Figure (3): The output hydrograph at return periods (25, 50, $100 \mathrm{yr}$.) 
Mountainous Lake: Flash flood water caused by rainfall of the return period 2 year are collected using a low cost technique (mountainous lake). This lake is a natural depression at the top of the mountain. Figure (4) shows the design drawing of this lake construction.

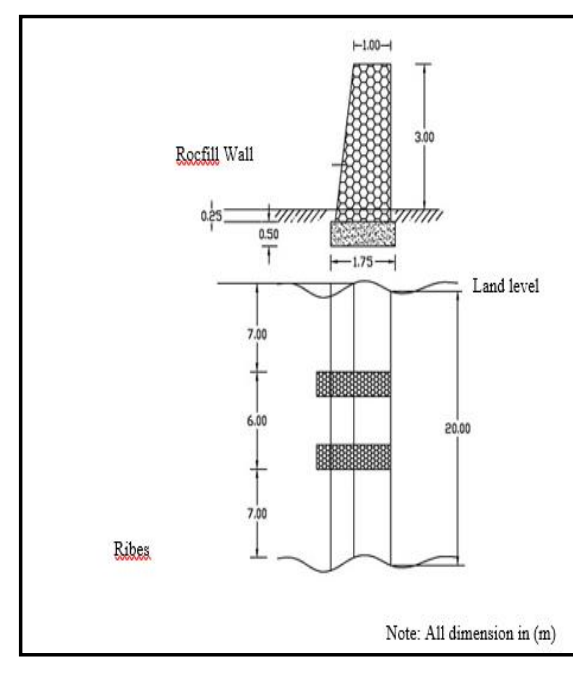

Rockfill wall

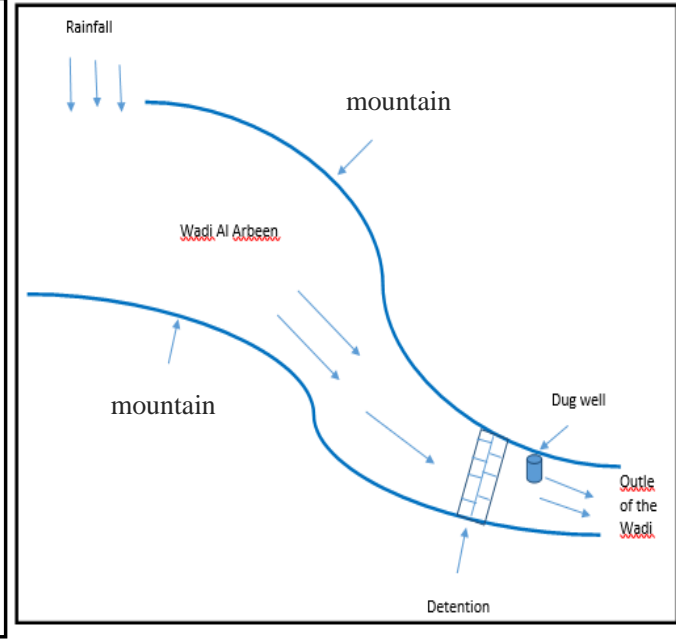

General layout

Figure (4): Design drawing of mountainous lake

Green House Implementation: A green house is implemented in Saint Catherine area. Four sites were investigated and water and soil samples were tested. field trip to Saint Catherine was carried out to select suitable locations for the greenhouse establishment and to investigate the sustainability of water. According to the samples analysis, the suitable location was chosen to establish the greenhouse. Some vegetable such as (tomato - cucumber) were cultivated and suitable organic and chemicals fertilizers were added. 


\section{RESULTS AND DISCUSSION}

The use of Harvested water: The harvested water during the year of 2017 was used in cultivating tomato and cucumber in the green house. Figure (5) presents the trend of irrigation quantity per week with time. The trend follows a liner regression with equation of $\mathrm{y}=24.093 \mathrm{x}-16.983$ with $\mathrm{R}^{2}=0.9994$ for tomato crop. Figure (6) While the trend of the irrigation quantity versus time for cucumber followed the equation $y=12.919 x-34.633$ with $\mathrm{R}^{2}=0.959$. the equation followed linear trend.

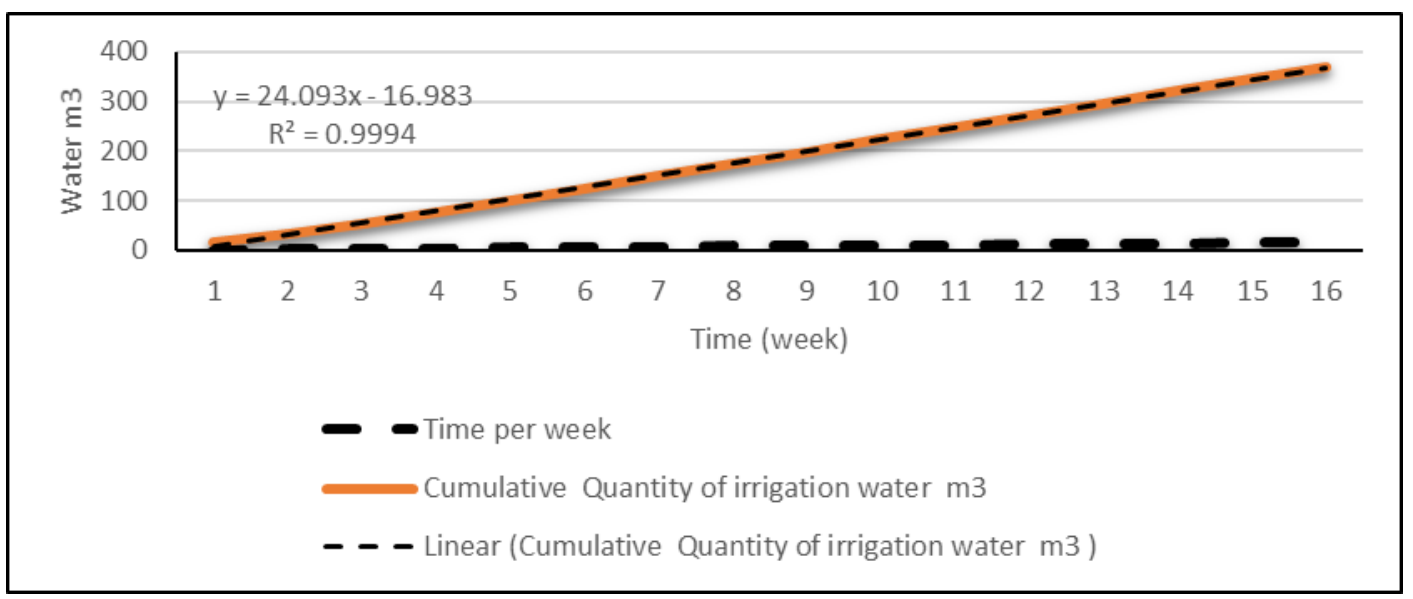

Figure(5): The trend of irrigation water applied to the tomato crop 


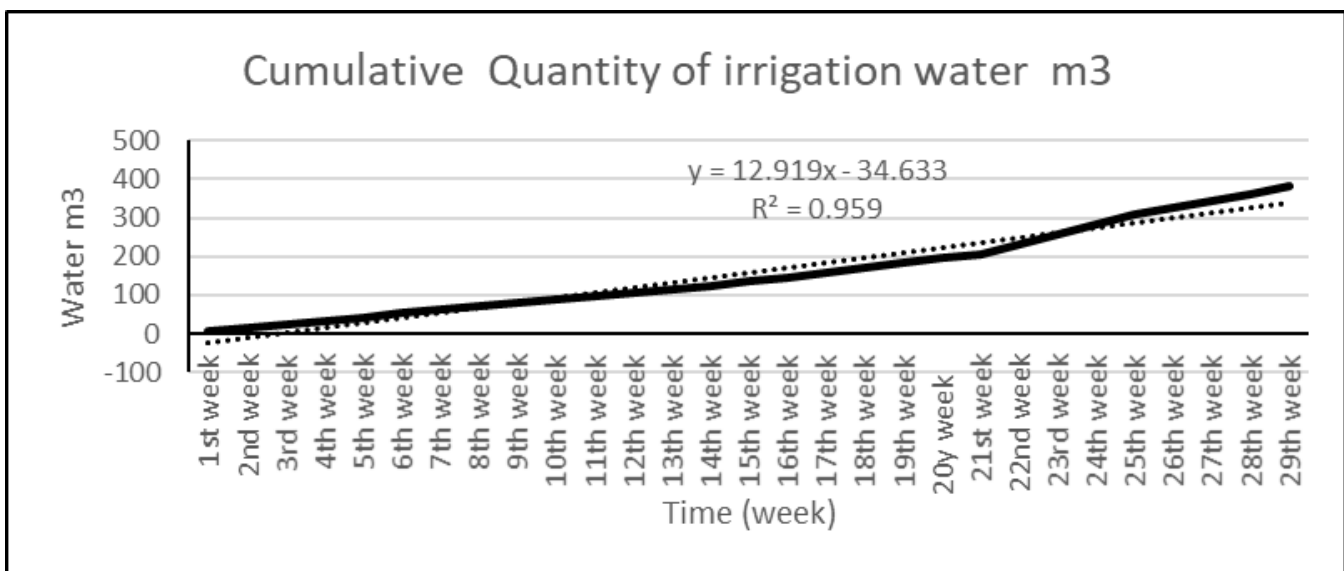

Figure (6): Cumulative quantity of irrigation water ( $\left.\mathrm{m}^{3} / \mathrm{Season}\right)$ applied to cucumber crop

Table (3) calculated the greenhouse that can be cultivated depending on the predicated volum es of water considering that the percentages of water that can be used assumed by 30 and $40 \%$ of the total predicated water.

The data present that depending on the predicated water that can be harvested and due to the water requirements for tomato and cucumber the number of green houses that can be cultivated increase with the increase of the return periods as shown in Figure (7). 
Journal of Environmental Sciences (JES)

Institute of Environmental Studies and Research, Ain Shams University

Abdel kader, Eman et al.

Table (3): Calculated of greenhouses that can be cultivated depending on predicated volumes of water

\begin{tabular}{|c|c|c|c|c|c|}
\hline $\begin{array}{l}\text { Return } \\
\text { periods } \\
\text { years } \\
\end{array}$ & $\begin{array}{c}\text { Predicated } \\
\text { volumes of } \\
\text { water } \\
\end{array}$ & $\begin{array}{c}* 30 \% \text { of total } \\
\text { volume }\end{array}$ & $\begin{array}{l}\text { *No. of } \\
\text { green } \\
\text { house } \\
\end{array}$ & $\begin{array}{l}40 \% \text { of total } \\
\text { volume }\end{array}$ & $\begin{array}{l}* \text { No. of } \\
\text { green } \\
\text { house } \\
\end{array}$ \\
\hline 2 & 2606.4 & 781.92 & 1 & 1042.56 & 1.0 \\
\hline 5 & 61434 & 18430.2 & 24 & 24573.6 & 32 \\
\hline 10 & 136602.9 & 40980.87 & 54 & 54640.8 & 72 \\
\hline 25 & 264409.2 & 79322.79 & 105 & 105763.68 & 141 \\
\hline
\end{tabular}

* No of greenhouse considering that each two greenhouses cultivated with tomato and cucumber as one

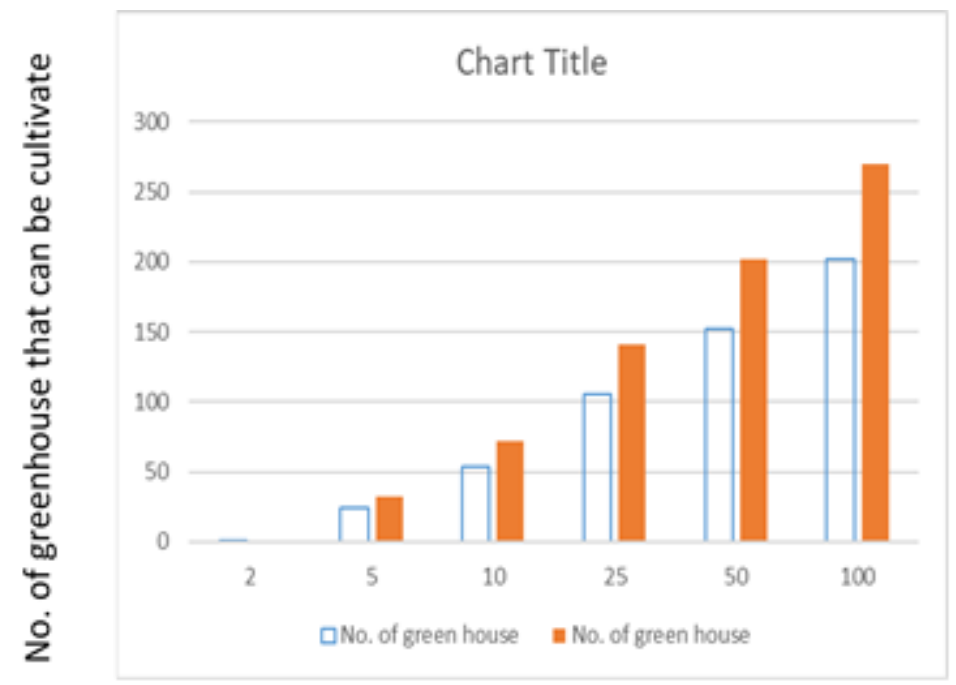

Figure (7): Return periods of flash floods 
Table(4): The productivities of cultivate crops and their costs

\begin{tabular}{|c|c|c|c|c|c|}
\hline Crop & $\begin{array}{c}\text { Total } \\
\text { costs L.E }\end{array}$ & $\begin{array}{c}\text { Productivity } \\
\text { Ton }\end{array}$ & $\begin{array}{c}\text { Field } \\
\text { price Ton } \\
\text { L.E }\end{array}$ & $\begin{array}{c}\text { Productivity } \\
\mathrm{Kg} / \mathrm{m} 2\end{array}$ & $\begin{array}{c}\text { Producity } \\
\mathrm{Kg} / \mathrm{m} 3 \\
\text { water }\end{array}$ \\
\hline Tomato & 1720 & 4.3 & 1995 & 15.95 & 11.36 \\
\hline Cucumber & 2082 & 5.2 & 2720 & 19.26 & 15.85 \\
\hline
\end{tabular}

Environmental Impact Assessment: The results of cultivating Tomato and Cucumber crops in green houses are presented in Table (4) the data show that the total costs were 1720 and 2082 Egyptian pound for Tomato and Cucumber respectively. The total productivities were 4.3 and 5.2 ton for Tomato and Cucumber respectively. The productivities of Tomato and Cucumber per $\mathrm{Kg} / \mathrm{m} 2$ were 15.95 and 19.26 respectively while the productivities for Tomato and Cucumber per $\mathrm{Kg} / \mathrm{m} 3$ of water were 11.36 and 15.85 respectively.

Depending on those results and the opinions of the scientist in the different areas of EIA, the following matrix was produced.

Table (5) The matrix considers the impact of the direct impact of flash flood occurrence and impact of constructing the dam to harvest the water of flash flood in order to use it in irrigation and avoid the problems that may be occurred.

\section{Environmental Impact Assessment of the cultivation process:}


Table(5): Environmental Impact Assessment Matrix

\begin{tabular}{|c|c|c|c|c|}
\hline \multirow[b]{2}{*}{ Item of Impact } & \multirow{2}{*}{$\begin{array}{l}\text { Flash flood } \\
\text { occurrence }\end{array}$} & \multicolumn{3}{|c|}{ Impact after Concentration } \\
\hline & & $\begin{array}{c}\text { After } 2 \\
\text { year }\end{array}$ & $\begin{array}{c}\text { After } 5 \\
\text { year }\end{array}$ & $\begin{array}{c}\text { After } 10 \\
\text { year }\end{array}$ \\
\hline Surface Water Availability & + & ++ & +++ & ++++ \\
\hline Groundwater Availability & + & ++ & +++ & ++++ \\
\hline Water Quality & + & ++ & ++ & ++ \\
\hline Soil Stability & - & + & + & + \\
\hline $\begin{array}{c}\text { Land Use } \\
\text { Land availability for } \\
\text { cultivation } \\
\text { grazing } \\
\end{array}$ & $\begin{array}{c}000 \\
-\end{array}$ & $\begin{array}{l}+ \\
0 \\
+\end{array}$ & $\begin{array}{l}++ \\
+ \\
+\end{array}$ & $\begin{array}{l}++++ \\
+ \\
+\end{array}$ \\
\hline Soil conservation & - & + & + & + \\
\hline Road Conservation & - & + & + & + \\
\hline $\begin{array}{c}\text { Economic Aspects } \\
\text { - land value }\end{array}$ & - & 0 & 0 & +++ \\
\hline $\begin{array}{c}\text { Social Aspects } \\
\text { Community Creation } \\
\text { Job opportunities } \\
\text { income } \\
\end{array}$ & $\begin{array}{l}- \\
-\end{array}$ & $\begin{array}{l}+ \\
+\end{array}$ & $\begin{array}{l}++ \\
++\end{array}$ & $\begin{array}{l}+++ \\
+++\end{array}$ \\
\hline Biodiversity & -- & + & ++ & ++ \\
\hline
\end{tabular}

Negative Impact

0 Zero Impact

+ Positive Impact 
Journal of Environmental Sciences (JES)

Institute of Environmental Studies and Research, Ain Shams University

Abdel kader, Eman et al.

\section{CONCLUSION}

\section{From the results and discussion the following can be concluded.}

- The quantities of water that precipitated due the flash flood differ according to the return period of the flash flood occurrence as calculated by Hydrological model.

- The model depending on some metrological parameter which are obtained from meteorological station that closed to the research site. Depending on those parameters the model can predicate the quantities of water via each return period.

- The quantities of water that predicted from the model via each return period were2606.4, 61434, 136602.9, 264409.2, 380076.3 and 507030.3 $\mathrm{m}^{3}$ via the return periods of $2,5,10,25,50$ and 100 years.

- The constructing of dam and building a lake or reservoir to store the water was effective to prevent the water losses and harvesting the rainfall water through recharge that water to the groundwater.

- The use of this water to cultivate tomato and cucumber in green house was a successful step in spite of the high costs in the first year for establishing the green houses, constructing the drip irrigation system, the costs of fertilizers pesticide application and the costs of the seeds.

- The crop yields of tomato and cucumber of the first year of cultivation were fair enough to compensate a big parts of the cost of cultivation and part from the costs of constructing the dam. In case of building many green 
Journal of Environmental Sciences (JES)

Institute of Environmental Studies and Research, Ain Shams University

Abdel kader, Eman et al.

house. the costs might be compensated within many few year of cultivation.

- The environmental impact assessment of the flash floods occurrence is completely negative for the different studied areas. The construction of the dam and build the lake help to mitigate the negative impacts of the flash flood and also achieve positive impacts for the different studied areas.

\section{RECOMMENDATION}

\section{The study recommended the following:.}

- Flash flood water is one of the water resources that should not be neglected.

- Harvesting flash flood water should be done by many methods depending on the frequency of occurring, the quantities, topography of the land and the characters of the land.

- The meteorological stations should be constructed closed the areas that exposed to the flash flood occurrence phenomena these stations should be checked, maintain from time to time.

- The model used for calculating the predicated quantities of water that might precipited should be continuously fed by meteorological data.

- The crops that might be cultivated depending the predicted quantities of water should be characterized the following:

- Their water requirements should be low.

- They can be cultivated in green houses. 
- The costs of the complete cultivation process should be low.

- The fruits or grains can be reserved and tolerant for transportation.

- The Environmental Impact Assessment should be applied for each project considering the different items related to that project.

\section{REFERENCES}

Al Zayed, I. S; Ribbe L. and Al Salhi, A. (2013): 5th International Conference on Water Resources and Arid Environments (ICWRAE 5): 159-166 7-9 January 2013, Riyadh, Saudi Arabia.

USA, Brigham Young University (2004): Water Modeling System (WMS) Software Version 7.1.

Chow, V. T; Maidment, D. R. and Mays, L. W, (1988): "Applied Hydrology, McGraw-Hill, New York, U.S.A".

Coral, C. (1987): Geologic Map of Egypt, Sheet NH-36-SE South Sinai Scale 1:500.

Global Water Partnership (GWP 2000): Integrated Water Resources Management, Technical Advisory Committee Background (TAZ) Paper 4. Stockholm, Sweden.

Intergovernmental Panel on Climate Change (IPCC 2001): Third Assessment Report. Cambridge University Press. Available at http://www.grida.no/climate/ ipcc_tar/wg1/).

Wagener, T., \& Gupta, H. V. (2005): Model identification for hydrologic forecasting under uncertainty. Stochastic Environ. Res. Risk Assess. doi:10.1007/s00477-005-0006-5. 
- Table of symbols

\begin{tabular}{|c|c|}
\hline Shortcuts & \\
\hline EIA & Environmental Impact Assessment \\
\hline WMS & Water Modeling System \\
\hline SCS & Soil Conservation Service \\
\hline $\mathrm{amsl}$ & above mean sea level \\
\hline $\mathrm{m} 3$ & Cubic meter \\
\hline $\mathrm{Kg} / \mathrm{m} 3$ & Kilogram per Cubic meter \\
\hline $\mathrm{Kg} / \mathrm{m} 2$ & Kilogram per meter square \\
\hline
\end{tabular}

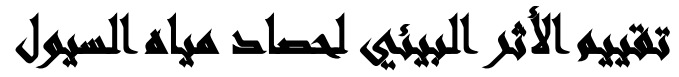

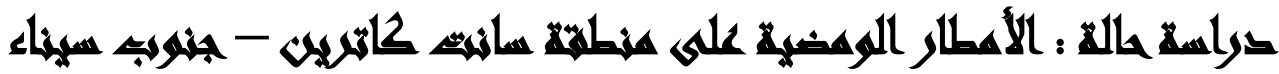

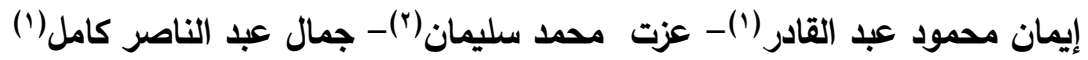

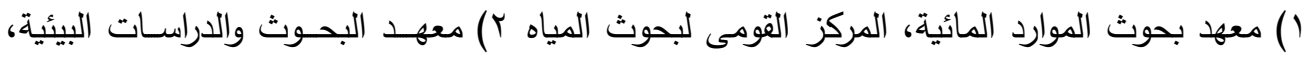
جامعـة عين شمس.

\section{المستخلص}

السيول هي ظاهرة كونية تحدث بسبب هطول الأمطار الكثيفة أو بسبب حدوث إنهيار في سد الإدار

وتحدث هذه الظأهرة في غضون ساعات قليلة. ويمكن تخفيف إضرار هذه الظاهرة

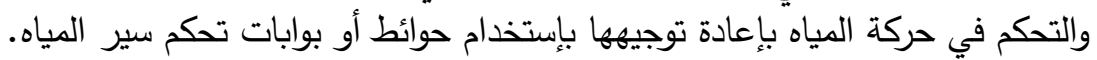

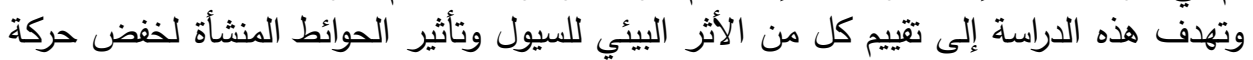

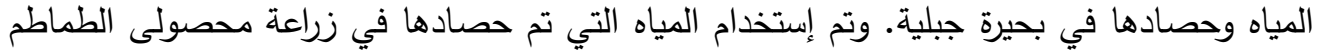

$$
\text { والخيار في صوب زجاجية. }
$$

وتوضح مصفوفة تقييم الأثر البيئي أن هناك تأثير إيجابى للبحيرة الجبلية لحصاد مياه السيول وإستخدامها في الزراعة في النواحى الاجتماعية والإقتصادية والتتوع البئية البيولوجى.

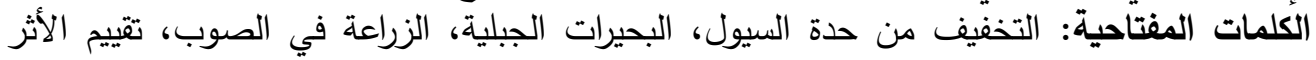
البيئي (EIA). (البمات المفتاحئ. 